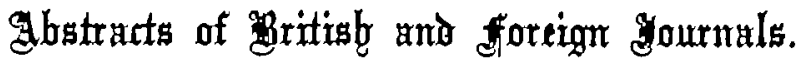

Kirchoff on Cerebral Glosso-pharyngo-labial Paralysis. (Archiv f. Psych. Bd. xi. p. 132.)-A man, ager 24, while perspiring profusely, stepped into water for a bathe. Scarcely had he done 8o, when he becume giddy, had convulsive tremors in his extremities, lost the power of speech, and was unable to swallow. Selive flowed from his mouth, and his face was drawn to the loft. These symptome disappeared in a few days, but a week later he had a similar attack. On admission into huspital, July 29, 1877, it was observed that he artionlated with difficulty; labials and gutturals especially were troublesome; linguals he spoke with comparative ease. The lips were moved little in speaking; he could not whistle, bat was able to approximate the lips. Saliva flowed from the mouth, and there was excessive secretion of teare. The tongue was not protrusible more than 1 centimetre from the mouth, and it was mored clumsily in the act of biting. At the time of examination swallowiug was unimpeded, but the glottis was alosed tardily. Patient often langhed without occasion. There was disease of the mitral valve.

During the progress of the there were marked remiagions and exacerbations. On November 2 swallowing was only possible with the head bent back, and even then was difficult. Saliva flowed from the mouth continually, and in his laugh, crowing and whistling sounde were often heard. His arms were shaky. On December 25 his faco was suddenly drawn to the right, and his left arm and leg becsme powerlese. Chronic convulsions ocourred from time to tiwe up to his death, on Jan. 5 .

The post-mortem revealed embolio softening of the posterior two-thirds of the right corpus striatum (candate nuclens ?), the nnderlying internal capsule, the outer segment of the lentioular nucleus, the claustram, external capsnle, and island of Reil. The fucus of softening in the lentionlar nucleus was distinguished from the other softened portions by being surrounded by a wall of compact solerosed tissue. Very careful microscopic examination failod 
to show any disease of the medulla or pons. The anthor attributus the glosso-lubial paralysis to the lesion of the lenticular nuoleus; and the hemiplegia to the quite recent lesion of the caudate nuolens, internal ospsula and other parts. Cases of bilateral affection of the faoe, tongne, and throst, caused by unilateral lesion of the cerebrum, are rare; the author cites two, recorded by Lépine and Magnus respectively.

Virchow on Progressive Facial Hemi-atrophy.-Virohow (Berliner klin. Wochonschr. 1880, No. 29, and abstract by Bernhardt in Centralbl. f. med. Wissensch. 1881, No. 3) reports two cases of this disease under the name of "neurotio atrophy." The first was a man, aged 42, whose face became atrophied on the left side in his ninth year. Virchow had seen the same patient twenty-one years previously, during. which time the disease had made no appreciable progress. The second case was a woman, aged 41 , in whom the disease had shown itself eixteen years ago, after an inflammatory affection of the skin of the left eye. Shortly before this the patient had fallen on the back of the head, and during childhood had often suffered from furunculas. There was atrophy not only of the left side of the face, but of a large area extending from the middle line of the back (between the fourth and seventh dorsel vertebry) outwards over the left infra-apinons fossa to the shoulder, and thenoe down the beok of the arm to the nlnar side of the furearm. The area of distribution of the left radial nerve was markedly atrophied. Tactile sensibility was normal; at one time sharp twinges of pain were felt in the eye and arm, but at the time of examination these had given place to a numb feeling in the arm and $u$ feeling of cold in the little finger. The author regards the disease, in its origin at least, as a peripheral affection of the nerves. The morbid process, inflammatory. or otherwise, may spread upwards till it reaches the ganglia in the basis cerebri or spinal column. The atrophio areas correspond to the course of various nerves, but not to the whole area of distribution of theee nerves; certain fibres only of the nerves become diseased. The author remarks that there are fow thinga in nerve pathology more striking than the unequal affection of the fibres of the same nerve in this disease. He regards lesion of the trigeminus as the starting point of the malady. The bones atrophy if the affection commences in the earlier years of life.

Flascher (Berliner klin. Wochenschr. 1880, No. 31) describes a case of bilateral facial atrophy, occurring in a woman aged 23. 
Whon sn infant she fell and injured her forehead, and shortly afterwards had an attack of measles, withont eraption. It was soon after this that the faoial atrophy appeared. The trigeminus, as a whole, was not implicated, but only partioular branches of it, and only particular fibres of these branches. In the atrophio places the vaso-motor system was unimpaired, tactile sensibility diminished, the secretion of sweat paralysed. The bones were atrophied, so also the facial muscles and the masseters and tomporals. There was external strabiamns of the left eje, the pupil of whiah was irregular, widely dilated, and non-reactile; sight was defective, and the optio diso atrophied and white. The weakness of sight and strabismus wore detected about the same time as the facial atrophy. Flasaher, too,-regards the disease as a peripheral affeotion of the nerves, coming on in this as a sequels of measlee.

Hammond (Jourm. Nerv. and Mont. Disease, April, 1880) observed a case of progresive facial atrophy in a girl, aged 14. The affection was of gradual growth, and did not attract attention till she was 12. There was a decided difference in the eize of the two ides of the face. On the left side there ware three depressions, two near the angle of the month, and one above and alightly in front of the ear. The left balf of the tongae was much maller than the right, and the palatine arch was flatter on the left than on the right side. Musoles supplied by the motor branch of the fifth nerve, by the faoial and by the ninth, were atrophied; miaroecopio examination of them showed atrophy without degeneration. There was no eppearance of paralygie. The skin, hairbulbs, cellular tissue, end even the bone (temporal) were also atrophied. There were ocarsional paroxysms of numbness lasting a fow minutes in the left side of the face. Defective sensibility was found only in a small region over the left half of the orbioularis oris. The author considers the nuclei of the trigeminus, facial, and hypogloses as the primary of the disease, which consists esentially in lesion of the trophio cells of these nuolei

Ealenbarg on Facial 8pasm. (Centrabl. f. Nervenheilk. 1880, No. 7, and Cbl. $f$. med. Wissenech. 1880, No. 47.)-A woman, aged 25, after an attack of transient sphasia, without loss of conscioneness, became subject to violent and painful contrations of the musoles of the left face, especially of the orbioularis pelpebrarum. In severe attecks the convalsions spread to the musoles supplied by the left spinal accessory, and to the flexors of the left hand and 
digits, and on rare occasions to the right side of the face and neok. There was hyperalgesia of the left face, and numerous painful points were found along the course of the trigeminal and facial nerves. Gelvanisation, bromide of potassiom, injections of atropine, morphine and ourare, and neurotomy of the supra-orbital nerve having proved ineffectual, the facial nerve was stretohed. The operation cared the spasm, bat left almost total paralyeis of the facial nerve. The muscles of the underlip were only partially paralysed, and thoee supplied by the posterior aurioular nerve were quite intact. A curious result was the abolition of the sense of taste in the anterior half of the left side of the tongne; sensibility and salivary secretion were normal. After a time epontaneous, intermittent fibrillary contractions, tonic-olonio in oharacter, appeared in the depression of the lower lip, which soon became the seat of a contraoture. Fifteen weeks after the operation, the sense of taste returned. As lesion of the chorda tympani is out of the question in this case, Eulenburg attributes the lose of taste to lesion of a filament, which, acoording to anatomists, is sometimes found conneoting the peripheral branches of the glosopharyngeal and facial nerves.

Mossdorf on Aphthongia - This was the name given by Fleury in 1865 to a variety of aphasia, characterised by spasm of the musoles supplied by the hypogloseal nervo whenever the patient attempts to speak. In Mossdorf's case (Cbl. f. Nervenheill. 1880, No. 1, and Arch. do Neurologie, 1880, No. 2), on the patient, a boy aged 17, attempting to speak, the hyoid and abdominal musoles became cramped, respiration oeaed, and through the halfopened mouth the tongue was ontracted, its tip firmly preseod against the lower incisors, and ite dorsum against the palate. In a few moments the abdominal muscles relared, and respiration was resumed, but the eparm of the tongue and hyoid musoles persisted. The movements of the tongae, lips, and face were, with this exception, quite normal Latterly the boy was unable to reply to his parents, or even read aloud when alone. The difficulty of speech showed itself when he was six years old, and was attributed to fright. A cure was effected by galvanisation; the negative pole was placed in the nape of the neck, and the positive pole slowly moved up and down the spine.

Sohultze on Multiple Cerebro-Spinal Bclerosis and General Paralysis,-Sahultzo (Arch.f. Prych. Bd. xi. p. 216) relates a case 
which, during the first two years of its course, was looked upon as corebro-spinal sclerosis. The symptoms were as follows: Tremors of the extremities during voluntary movements, paresis of the legs and of the right arm, paius in the extremities, impaired sensibility of the right arm, at times incontinence of urine, hallucinations of sight, diplopia, vertiginous seizures, epileptiform attacks, slow, stuttering, monotonous speech. There were marked remissions in the symptoms, and twice the gait of the patient, who, we may mention, had suffered from ayphilis, so far improved that he was disoharged. On his third admission into hospital, mental disturbances for the first time showed themselves. He became acutely maniacal, had grandiose ideas, and presented up to the time of his death the typical symptoms of general paralysis. It is a remarkable fact that tremors were never observed during voluntary movements after the appearance of the mental disorder. On past-mortem examination there was found, in addition to the usnal accompaniments of general paralysis (diffuse hyperplasia of the connective tissue and atrophy of the cerebrum), multiple soleroeis of the cord and diffuse sclerosis of the brain. In another case of general paralysis, the author found amall patches of solerosis in the cord, and diffuse sclerosis in both cord and cerebrum.

The concurrence of the two diseases, multiple sclerosis and general paralysis, rare though it seems to be (a case by Claus is reported in 'BraIN,' Vol. II. p. 142), is only what might be expected from their pathology, for they are both characterised by a wideupread hy pertrophy of the neuroglia with the formation of granulecelle. Solerotio ohanges in the cord, particularly in Gall's colnmns, and the pyramidal strands ocour frequently in general paralysis.

The first ofse offers a few subsidiary points of interest:-(1.) the cord in the fresh state appeared quite normal ; it was only after immersion in Muller's fluid that the sclerosed patches became visible. (2.) Though the whole area of the posterior columns was selerosed in the lower part of the dorsal region, and again in the lower part of the cervical enlargement, there was but slight secoudary degeneration of -Goll's culnmns. The lateral pyramidal strands were degenerated through the greater part of the cord, but in the npper cervical region were quite intact, which shows that the degeneration was of spinal origin. The relation of multiple sclerosis to secondary degenerstions is still far from alear. Schultze suggests that the pyramidel strande and Goll's columns are, from their anatomical constitntion, the parts that suffer most severely in general hyperplasia of the connective tissue of the 
cord. (3.) Corresponding to the jeolated atrophy of the interosei musoles of the right hand, there was lesion of the right anterior cornu in the lower part of the cervical enlargement, which coinoides with other observations bearing on the localisation of the spinal centres for the omall muscles of the hand.

Seeligmüller and Schmid on Hereditary Ataxia.-Seeligmeller relates the histories of two brothers who suffered from this disease. The younger, aged 26, showed symptoms of ataxia of the lower extremities when 12 years old. Ten years later, nystagmus developed, and quite recontly slight ataxia of the superior extremities had been observed. The ataxia of the lege was visible both in walking and in standing with the feet together (otatio ataxia). The movements of the eyes had not the usual rythmical character, but were more irregular and jerking, and corresponded with Friedreich's atactio nyetagmus. There were no fibrilly contraotions, except slight ones in the protruded tongue; sensibility and electrical irritability of nerve and musole were normal ; there pere no paralyses, contractures, or atrophies. The secretion of saliva was abnormally abundant. This ase differs from those described by Friedreich in the following points: (1) There was no ataxia of epeech; (2) the patellar refleres were heightened, not absent; (3) there were cerebral symptoms, in the shape of peychical manifestations, e.g. forgetfulness, tendency to reverie, perverted sexual instincts, and melancholia when 16 years old; and (4) there was occasional impairment of the vesical and anal sphincters. In the elder brother, aged 28, the nystagmus and the statio and locomotor ataxia of the lower extremities were less marked. The npper extremities were nnaffeoted. The patellar reflex was lively, ensibility intact. The patient was forgetfal and absent in mind; he spoke very rapidly, but sometimes not very intelligibly, as he would hurry from entence to sentence withont finishing them. Father and mother were cousins, and nervous diseases were common in the family.

Sohmid's case (Contralblath f. mod. Wisenech. 1880, No. 25) wus a boy of 18, whose gait five years befure had bocome nnoertain and peouliarly rapid, and at length resembled that of a drunken man. There was marked locomotor and static ataxia of the lower extremities, and sjight incoordination in the movement of the arms. Closing the eyes, or being in darknese, did not intensify these symptoms. Muscular power and electrical irritability were normal, the superficial reflexes unaffected, the patellar reflex 
absent. Speoch was halting and inartioulate, and the eyes exbibited nystagmio movements. Sensibility was intact, and the sphinoters acted naturally. There were no mental symptoms. At a later periud the patient became unable to walk, and slight sensory disturbances were noticed in the lower extremities. A younger brother, when 11 years old, began to show symptoms of locomotor atario, and his patellar refler diseppeared. A sister, aged 9, is heslthy up to the present. There was no speoial tendency to neuroses in the family.

Romak on Localised Ataxia and Ephidrosis. (Berliner klin. Wochenochr. 1880, No. 22, and Centralbl. f. med. Wissensch. 1880, No. 51.) - A man aged 38, infeoted with syphilis twelve years previously, had suffered for five years from gradually increasing anesthesia of the right forearm, hand, and fingers. The movements of the limb were in a high degree ataxio, but not diminished in strength. Shortly after the apperance of the ataxia, excesive seoretion of Bweat was observed on the right helf of the head, and slight reddening of the face. 'There was myosis of the left eye. Lately symptoms had developed which suggested commencing tabes-unsteadiness of gait in derkness, or when eyes were shut, a feeling of numbness in right sole, difficulty in mioturition, absence of patellar reflex. The author diagnosed a patch of salerosis in the right posterior half of the cervical enlargement, with secondary changes in both posterior columns. The unilateral ephidrosis may be due to lesion of the cerebro-spinal secretory centree, or perhaps to lesion of the cervical sympathetio.

W. J. DODLs, M.D., B.Sc.

\section{Gaucher on the Morbid Anatomy of Diphtheritic Para-} 15sis.-Gauoher (Journal de I Anatomie, No. 1, 1881) reports the result of an investigation of two cases of Diphtheritio Paralysis. In one of these no lesion was discoverable, either in the muscular or nervous eystem. In the second, however, there were wellmarked appearances corresponding in most points with those described by Dejerine as characteristio of this form of paralyeis. Dejerine had found that the esential lesion was a parenohymatous neuritis of the anterior roots of the spinal cord, aharaoterised by a segmentation of the myeline and multiplication of the nuclei in the sheth of Sohwann with complete or partial disappearance of the axis cylinder. Further, in the anterior horns, the cells were less numerons, rounded and deprived of their procerses. 